\title{
Major Depressive Disorder and Kappa Opioid Receptor Antagonists
}

\author{
Wei $\mathrm{Li}^{1}$, Huijiao Sun ${ }^{1}$, Hao Chen ${ }^{1}$, Xicheng Yang ${ }^{1}, \mathrm{Li} \mathrm{Xiao}^{1}$, Renyu $\mathrm{Liu}^{2}$, Liming Shao ${ }^{1}$, , Zhuibai Qiu ${ }^{1}$ \\ ${ }^{1}$ Department of Medicinal Chemistry, School of Pharmacy, Fudan University \\ ${ }^{2}$ Department of Anesthesiology and Critical Care, Perelman School of Medicine, University of Pennsylvania
}

\begin{abstract}
Major depressive disorder (MDD) is a common psychiatric disease worldwide. The clinical use of tricyclic antidepressants (TCAs), monoamine oxidase inhibitors (MAOIs) and selective serotonin reuptake inhibitors (SSRIs)/ serotonin-norepinephrine reuptake inhibitor (SNRIs) for this condition have been widely accepted, but they were challenged by unacceptable side-effects, potential drug-drug interactions (DDIs) or slow onset/ lack of efficacy. The endogenous opioid system is involved in stress and emotion regulatory processes and its role in MDD has been implicated. Although several KOR antagonists including JDTic and PF-04455242 were discontinued in early clinical trials, ALKS 5461 and CERC-501(LY-2456302) survived and entered into Phase-III and Phase-II trials, respectively. Considering the efficacy and safety of early off-label use of buprenorphine in the management of the treatment-resistant depression (TRD), it will be not surprising to predict the potential success of ALKS 5461 (a combination of buprenorphine and ALKS-33) in the near future. Moreover, CERC-501 will be expected to be available as monotherapy or adjuvant therapy with other first-line antidepressants in the treatment of TRD, if ongoing clinical trials continue to provide positive benefit-risk profiles. Emerging new researches might bring more drug candidates targeting the endogenous opioid system to clinical trials to address current challenges in MDD treatment in clinical practice.
\end{abstract}

Keywords: Major depressive disorder; Kappa opioid receptor; Antagonists

\section{Brief Introduction of Major Depressive Disorder}

Unlike other depressed mood which might be a normal reaction to life events, major depressive disorder (MDD) is a psychotic disorder, with chief manifestations of depressed mood, generalized anxiety, irritability or guilt. Besides-these negative emotions, MDD is also associated with changes in physical, social and intellectual functions, resulting in a significant incapability or disability. In severe conditions, patients may experience delusions, hallucinations, suicidal ideation or behavior.

According to World Health Organization (WHO), it has been estimated that more than 350 million people were affected by depression. ${ }^{[1]}$ In the United States, major depression has a point prevalence of approximately 3 to $5 \%$ in males and 8 to $10 \%$ in females. Lifetime prevalence is up to $10 \%$ in males and 20 to $25 \%$ in females. ${ }^{[2]}$ There were no formal epidemiological studies on MDD conducted in China. However, a meta-analysis ${ }^{[3]}$ demonstrated that the overall estimation of current, 12-month and lifetime prevalence of MDD was 1.6, 2.3, 3.3\% respectively in Mainland China. Moreover, the World Mental Health Survey Initiative from 18 high and low- to middle-income countries found that the 12-month prevalence of Major Depressive Episodes (MDE) was 3.8\% in China, similar to that in high-income countries. But the lifetime prevalence of $\mathrm{MDE}^{[4]}$ was somewhat lower in China (12.0\%) than in high-income countries (28.1\%). Thus, MDD represents a major threat to both developed and developing countries worldwide.

\section{Current Antidepressants with Clinical Relevance}


Tricyclic antidepressants (TCAs) were firstly introduced during the era of explosive birth of psychopharmacology in 1950s. These agents exert their anti-depressive effects mainly by blocking the serotonin transporter (SERT) and the norepinephrine transporter (NET). However, due to the promiscuous nature of pharmacology, there are additional anticholinergic, antihistaminic and antipsychotic components ${ }^{[5]}$ of most TCAs, which are associated with respiratory depression, seizures, urinary retention and cardiovascular toxicities. To date, TCAs, such as imipramine (1) ${ }^{[6]}$, clomipramine (2) ${ }^{[7-10]}$ and amitriptyline (3) ${ }^{[11,12]}$ are recommended as the multi-line therapies for patients with major depression.

MAOIs (monoamine oxidase inhibitors, e.g., isocar-

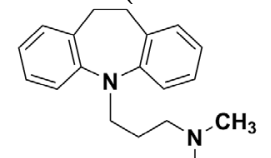

imipramine (1)

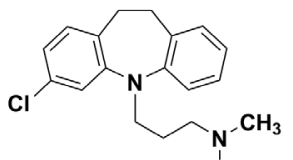

$\mathrm{CH}_{3}$

clomipramine (2)

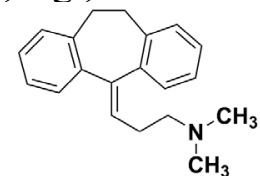

amitriptyline (3)

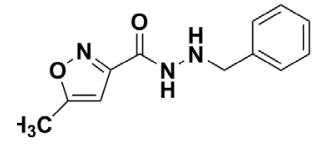

isocarboxazid (4)

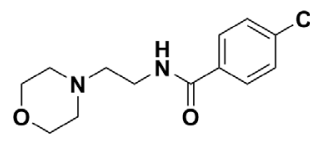

moclobemide (5)

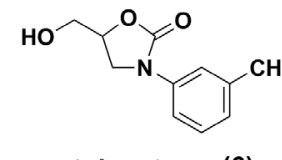

toloxatone (6) boxazid (4),,$^{[13-15]}$ moclobemide (5),,$^{[16-18]}$ and toloxatone (6) ${ }^{[19]}$ ) represent another category of anti-depressants. ${ }^{[20,21]}$ These agents inhibit the activities of monoamine oxidases, which are responsible for oxidation and inactivation of monoamine neurotransmitters (e.g., serotonin, dopamine and norepinephrine). The potential interaction between MAOIs and tyramine-enriched food might lead to severe or fatal hypertension. ${ }^{[22,23]}$ Moreover, since monoamine oxidases bear similar structures and functions to cytochrome P450 enzymes, most MAOs were also identified as drug-metabolizing enzymes and could induce potential drug-drug interactions. Today, MAOIs have been indicated for the treatment of depression when other treatments failed to work. ${ }^{[24]}$

The availability of selective serotonin reuptake inhibitors (SSRIs) in 1980s changed the management of MDD significantly. ${ }^{[25]}$ Citalopram ${ }^{[26,27]}$ (as well as the $S$ - enantiomer escitalopram (7), ${ }^{[28-30]}$ ) sertraline (8) ${ }^{[31-33]}$ and fluoxetine (9) ${ }^{[34]}$ have become the most prescribed antidepressants in many countries. SSRIs are effective, more tolerable and safer over TCAs or MAOIs. Introduction of a norepinephrine component yielded serotonin-norepinephrine reuptake inhibitors

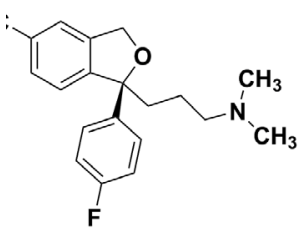

escitalopram (7)

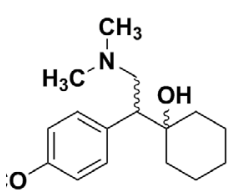

venlafaxine (10)

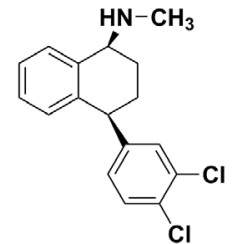

sertraline (8)

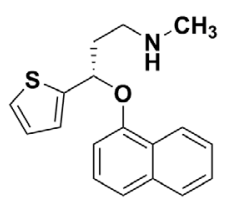

duloxetine (11)

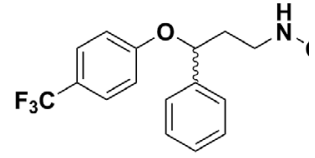

fluoxetine (9)

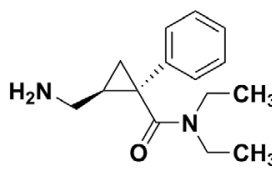

milnacipran (12) (SNRIs), such as venlafaxine (10), ${ }^{[35-37\rfloor}$ duloxetine (11), ${ }^{[38,39]}$ milnacipran (12). ${ }^{[40,41]}$ These agents are believed to deliver similar potent anti-depressant activities and also to be effective for the treatment of neuropathies. ${ }^{[42,43]}$

Both SSRIs and SNRIs are the most used first-line anti-depressants worldwide. However, some challenges remain unresolved. Patients with MDD might not benefit from SSRIs until after 2-4 weeks of treatment. Such slow-onset places a heavy emotional and psychological burden on patients with MDD. ${ }^{[4,45]}$ Many researchers are expediting the discovery of agents with inhibitory activities against multiple monoamine reuptake, such as SNDRIs, or triple re-uptake inhibitors, aiming to avoid prolonging the treatment phase before attainment of optimal efficacy expectation ${ }^{[46]}$. But too much dopamine activity might have dose-limiting factors due to its stimulant effect. Currently, no triple re-uptake inhibitors have been marketed to date, but a few candidates have already entered into clinical trials (e.g., LY03005, EB1010, SEP-225289). Moreover, approximately $30-40 \%$ patients complained of lack of efficacy during the treatments of SSRIs or SNRIs, which represents a major unmet medical need. ${ }^{\left[{ }^{[7-49]}\right.}$ Patients who responded poorly have to turn to less preferred treatments with a combination of multiple drugs. In October 2004, FDA required manufacturers of antidepressant medications to add a black-box warning that these medications, specifically fluoxetine, sertraline and other SSRIs, may increase suicidality in children and adolescents less than 24 years old, as indicated in studies of MDD and other psychiatric disorders. ${ }^{[50-53]}$ This warning reduced the use of SSRIs or SNRIs for pediatric patients with MDD.

While the monoamine deficiency hypothesis is undoubtedly successful, leading to the successful development of MAOIs as antidepressants, MAOIs only 
relieves some of the patients with MDD. Current research is focused on the identification of novel targets and relevant ligands to resolve the unmet need-as depicted above.

\section{Kappa Opioid Receptor (KOR) as a Druggable Target for Depression}

The association between the endogenous opioid system and mood regulation has been well established. ${ }^{[54]}$ Most opioids with clinical relevance are practically Mu opioid receptor (MOR) agonists, which are effective for most of the severe pain. MOR agonism is associated with analgesia, euphoria and mood changes, as well as dose-limiting side effects, such as constipation, respiratory depression and addiction. In contrast, KOR is another member of the opioid receptor family, whose agonism results in as analgesia, dysphoria, hallucination, and psychotomimetic effects. ${ }^{[55,56]}$ The endogenous dynorphin-KOR system is now being extensively investigated in rodent models for its role in depression to explore the potential use of KOR antagonist in the treatment of depression ${ }^{[57-61]}$. KOR has been proposed to be involve in the stress system implicated in depression pathophysiology and was identified as an important component in depression and other psychiatric disorders characterized by reward dysfunction. ${ }^{[58,59,62]}$ The development of KOR antagonists as potential antidepressants are mainly driven ${ }^{[63]}$ by their antidepressant-like effects in in vivo studies. ${ }^{[64]}$ The prototype of non-peptide KOR antagonist, nor-BNI, could produce antidepressant-like effects in both forced-swimming (FS) ${ }^{[65]}$ and learned helplessness (LH) ${ }^{[66]}$ assays in rodent models. Other selective KOR antagonists (e.g. JDTic) also showed antidepressant-like effects in vivo. ${ }^{[67,68]}$ Moreover, the pan opioid antagonist naloxone against all opioid

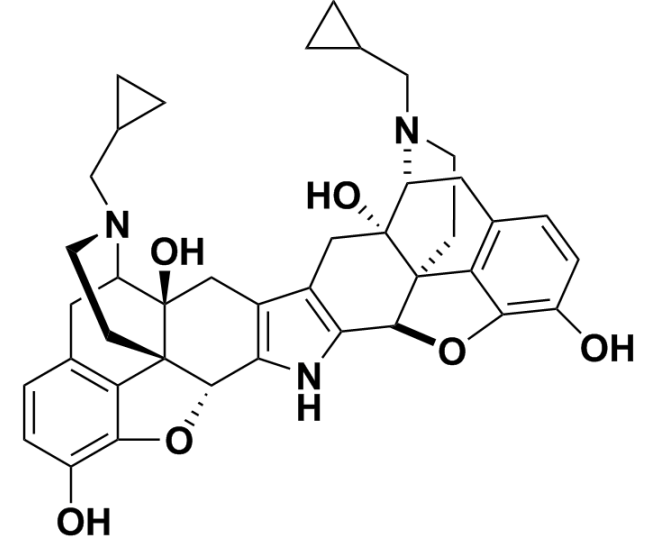

nor-BNI (13)

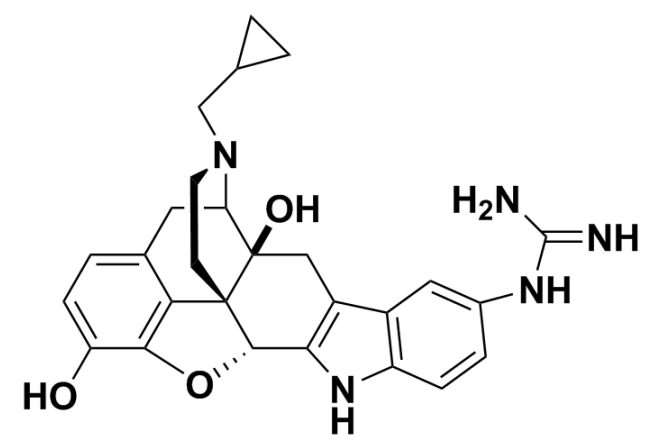

GNTI (14) receptors was also found to have antidepressant effect in the learned helplessness (LH) model. ${ }^{[69]}$

\section{Opioid Receptor Antagonists as Potential Anti- depressants}

Early interest for KOR ligands were stemmed from the discovery of U50488 [70] in the 1980s, an arylacetamide without the opiate motif but with highly selective KOR agonistic activities. With U50488 as the prototype of kappa full agonists, a large family of related compounds have been synthesized and a few (e.g., spiradoline, enadoline) candidates were brought to clinical trials in 1990s. However, the clinical trials were terminated early due to the dose-limiting toxicities of dysphoria, hallucinations and psychotomimetic effects. ${ }^{[71,72]}$ In contrast, KOR antagonists were initially developed as pharmacological tools to characterize KOR and its agonists, but their potential clinical use as potential antidepressants were not addressed until recently. ${ }^{[64]}$

\subsection{Opiate Derived KOR Antagonists}

\section{Nor-binaltorphimine (13)}

Nor-binaltorphimine (nor-BNI) was described as a highly selective and potent non-peptide KOR antagonist in late 1980s. ${ }^{[73]}$ It is a bivalent dimer of naltrexone via a pyrrole ring in its structure. ${ }^{[74]}$ nor-BNI demonstrated a high affinity to $\operatorname{KOR}\left(\mathrm{K}_{\mathrm{i}}=0.26 \mathrm{nM}\right)$ in guinea pig brain. ${ }^{[75]}$ While in guinea pig ileal (GPI) longitudinal muscle preparations, the antagonistic potency of this compound was determined to be $0.41 \mathrm{nM}$ for the KORs ${ }^{[76]}$, with approximately 170 and 150 times more potency than for mu and delta opioid receptors (DOR), respectively. ${ }^{[77]}$ For pharmacokinetic characteristics, nor-BNI at a dose of $20 \mathrm{mg} / \mathrm{kg}$, s.c.

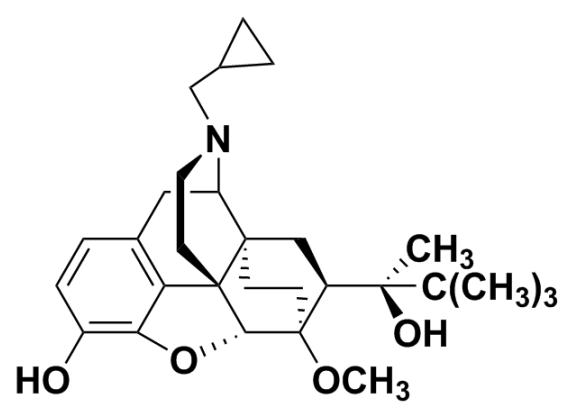

buprenorphine (15) 
demonstrated a biphasic elimination pattern in mice, with the rapid phase for $0.75-4$ hours and the slow phase for 4-48 hours respectively. ${ }^{[78]}$ Pharmacodynamically, the extremely long-acting mechanism of nor-BNI was shown in the blocking of the analgesic effect induced by U69,593 and bremazocine for up to 504 hours in vivo. ${ }^{[79]}$ As a consequence, there are significant concerns of drug accumulation for developing non-BNI as a clinical medication.

\section{GNTI (14)}

5 '-guanidinonaltrindole (GNTI) was synthesized and characterized by Portoghese and coworkers from the highly selective DOR antagonist naltrindole. ${ }^{80]}$ GNTI is also a natrexone derivative, but it is structurally dissimilar to nor-BNI. Later Structure-activity Relationship (SAR) analysis demonstrated that both compounds bear similar structural loci for KOR selectivity, especially for the relatively conserved basic component, which was confirmed by site mutatgenesis studies. ${ }^{[63]}$ GNTI has a Ki value of $0.14 \mathrm{nM}$ for KOR transiently expressed in rat HEK-293 cells [Ki ratio: $\mathrm{MOR} / \mathrm{KOR}=712$ ? $\mathrm{DOR} / \mathrm{KOR}=177]$, ${ }^{[81]}$ with an approximate four-fold increase compared to nor-BNI. It also demonstrates high KOR antagonistic activities $\left(\mathrm{K}_{\mathrm{e}}=0.16 \mathrm{nM}\right)$ in Guinea-pig ileum (GPI) preparations. By intramuscular administration, GNTI could reverse the effects of the KOR selective agonist U50, 488 on rhesus monkeys dose- and time-dependently, and its pharmacokinetics is characterized by a slow onset and long duration of action, with its antagonistic effect peaking after 24 hours. ${ }^{[82]}$ However, GNTI is orally inactive probably due to its poor blood-brain barrier (BBB) penetration as the consequence of a fully ionized guanidinium group in its structure. ${ }^{[83]}$

\section{Buprenorphine (15)}

Buprenorphine is a semisynthetic opioid derived from the opiate alkaloid thebaine. It was initially developed as a long acting analgesic for chronic pains ${ }^{[84]}$ and substitution treatment for opioid addiction. ${ }^{[85-87]}$ Due to its unique KOR antagonistic and MOR partial agonistic activities, the anti-depression potential of buprenorphine has been investigated extensively in animal models ${ }^{[88]}$ and clinical trials. ${ }^{[86,87,89]}$ An early open label study in patients with treatment-refractory, unipolar, nonpsychotic, major depression, suggested a possible role of buprenorphine in the treatment of refractory depression. ${ }^{[90]}$ Low-dose buprenorphine may be a novel medication that provides a rapid and sustained improvement for older adults with treatment-resistant depression. ${ }^{[91]}$ Despite of these encouraging results, there is a mu opioid component involved in the pharmacological profile of buprenorphine, potentially resulting in opioid-like side effects, such as nausea, constipation and dyspnea. ${ }^{[92,93]}$

ALKS 5461, a fixed combination of buprenorphine and ALKS 33 (samidorphan, 16) for sublingual administration, has been developed by Alkermes as a potential treatment for patients with MDD not responding to SSRIs or SNRIs. ALKS 33 is a full MOR antagonist, which was employed to reverse the known side effects induced by the Mu opioid component of

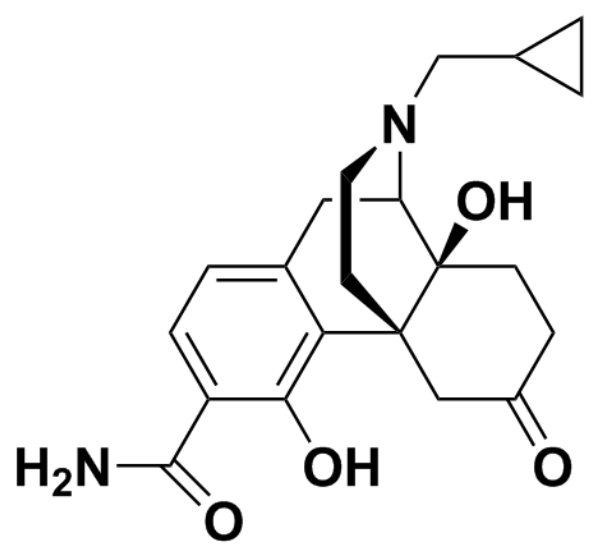

ALKS 33 (16)

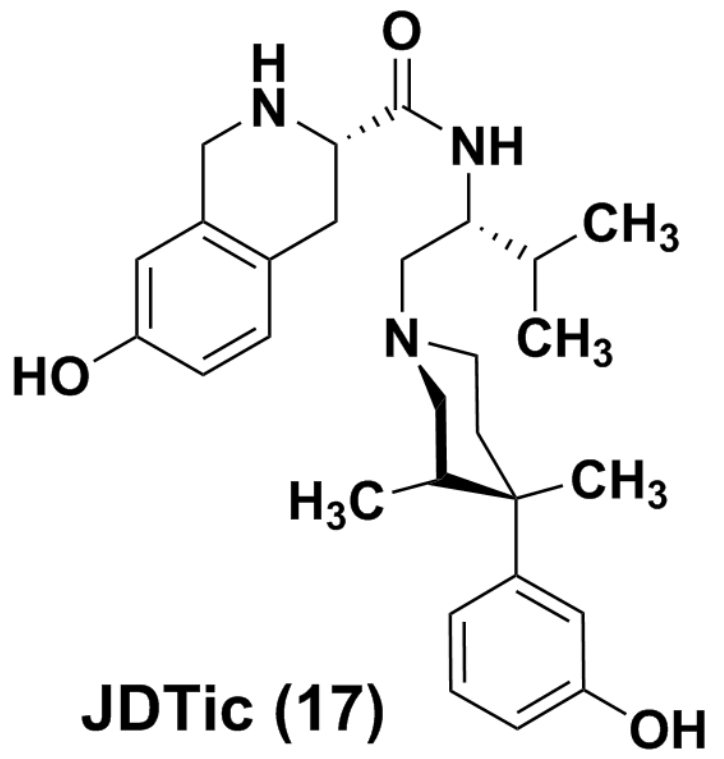


buprenorphine. In a randomized, double-blind, placebo-controlled phase II study in subjects with major depressive disorder (ClinicalTrials.gov Identifier: NCT01500200), ALKS 5461 demonstrated evidence of efficacy in patients with MDD not responding to SSRIs or SNRIs. Moreover, a substantial effect was-attained after treatment for seven days. ALKS-5461 was granted Fast Track Designation by the Food and Drug Administration (FDA) for treatment-resistant depression in October 2013. Phase III trials were initiated in 2014 and the preliminary results were favorable. If ALKS 5461 were to be authorized successfully in late 2016 or 2017, it might meet some medical need for patients inadequately controlled by SSRI and SNRI monotherapy.

\subsection{JDTic (17)}

With pethidine (also known as meperidine) as the prototype, the synthetic opioid analgesic of the phenylpiperidine class has a relatively long history of clinical use. In 1978, Zimmerman and co-workers described that introduction of a unique (3R, 4R)-dimethyl substitution results in $(3 R, 4 R)$-Dimethyl-4-(3-hydroxyphenyl)- piperidines (e.g., LY272922) as non-selective opioid antagonists ${ }^{[94]}$. Based on the structure of JPP- 6 with KOR binding other than functional selectivity, ${ }^{[95]}$ Carroll and co-workers at Research Triangle Institute (RTI International) discovered JDTic ${ }^{[96]}$ to be a potent, long and orally-active selective KOR antagonist, although it was later considered that neither the 3-methyl nor 3, 4-dimethyl groups present in JDTic and analogs are required to produce potent and selective KOR antagonists. ${ }^{[97]}$

Besides its high KOR binding affinity $(\mathrm{Ki}=0.32 \mathrm{nM})$ in guinea pig brain, the extremely high antagonism and selectivity over other opioid receptors of JDTic was confirmed in agonist stimulated $\left[{ }^{35} \mathrm{~S}\right] \mathrm{GTP}-\gamma-\mathrm{S}$ Binding assay of Cloned Opioid Receptors $\left(\mathrm{K}_{e}=0.006\right.$ $\mathrm{nM}, \mathrm{MOR} / \mathrm{KOR}$ ratio=570, $\mathrm{DOR} / \mathrm{KOR}$ ratio $>16600)$. JDTic could antagonize the antinociceptive effects of the KOR agonist U50, $488 \mathrm{H}$, but had no effect on morphine-induced behaviors in mice. In U50, 488-induced diuresis rat test, JDTic, suppressed diuretic activity with a greater potency than that of nor-BNI ${ }^{[98]}$. The psychiatric effects of JDTic were also investigated in a number of rodent models, such as nicotine reward, ${ }^{[99]}$ alcohol seeking and withdrawal anxiety, ${ }^{[100,101]}$ as well as opiate abuse, ${ }^{[102]}$ and promising findings were observed. After intraperitoneal injections in mice, the brain concentration of JDTic peaked within 30 minutes and decreased gradually over a week, despite a mechanism of P-gp-mediated efflux ${ }^{[83]}$. The high apparent volume of distribution and slow elimination from the brain for JDTic suggest a very high tissue affinity. ${ }^{83]}$

The first human trial of JDTic was halted abruptly in May 2012 due to apparent clinical toxicity (non-sustained ventricular tachycardia (NSVT)). ${ }^{[103]}$ However, this cardiotoxicity was not observed in both in vitro and in vivo assays before human studies. Further investigation is needed to determine whether observed cardiac involvement is specific to JDTic or possibly represents a class effect of KOR antagonists. ${ }^{[104]}$

\subsection{KOR Antagonists from Pharma R\&D Pipeline CERC-501 (18)}

CERC-501 (formerly known as LY-2456302) ${ }^{[105]}$ which was originally developed by Eli Lilly and later<smiles>Cc1cc(C)cc([C@H]2CCCN2Cc2ccc(Oc3ccc(C(N)=O)cc3F)cc2)c1</smiles>

CERC-501 (18)

PF-04455242 (19)

AZ-MTAB (20) 
by Cerecor, is a non-peptide, short-acting KOR-selective antagonist $\left(\mathrm{K}_{\mathrm{i}}=0.813 \mathrm{nM}, \mathrm{MOR} / \mathrm{KOR}=21\right.$ aDOR/ $\mathrm{KOR}=135$ ). This compound demonstrates a $>30$-fold functional KOR selectivity over MORs and DORs. Oral administration of CERC-501 could reverse the analgesia induced by $\mathrm{U} 69593(1 \mathrm{mg} / \mathrm{kg}$, sc $)$ in rat formalin assays $\left(\mathrm{ED}_{50}=0.4 \mathrm{mg} / \mathrm{kg}\right)$, whereas no reversal effects were observed after 1-week of pre-treatment ${ }^{[105]}$. In mouse forced swim assays, $10 \mathrm{mg} / \mathrm{kg}$ oral dose of CERC-501 was found to reduce immobility responses similarly to an optimal dose of the TCA imipramine $(15 \mathrm{mg} / \mathrm{kg}$, ip). A synergic effect was also observed for CERC-501 (3 mg/kg, po) and citalopram ( $3 \mathrm{mg} / \mathrm{kg}$, ip) in combination, thus suggesting that CERC-501 may augment antidepressant efficacy in patients who do not achieve adequate improvement of depressive symptoms on standard MAOI medications. ${ }^{[105]}$ CERC-501 has rapid absorption $\left(\mathrm{t}_{\max }: 1-2 \mathrm{~h}\right)$ and good oral bioavailability $(\mathrm{F}=25 \%)$. ${ }^{\left[{ }_{\max } 606\right.}$

In clinical trials, CERC-501 displayed rapid oral absorption and a terminal half-life of approximately $30-40$ hours in healthy subjects ${ }^{[107]}$. Plasma exposure of CERC-501 increased proportionally with increasing doses and reached steady state after 6-8 days for once-daily dosing ${ }^{[107]}$. A proof-of-concept trial of CERC-501 for augmentation of antidepressant therapy in treatment-resistant depression was initiated in April 2015, and the results are estimated to be available in December 2016.

\section{PF-04455242 (19)}

PF-04455242, developed by Pfizer, is a novel KOR antagonist from biphenyl derivatives. It demonstrates a high affinity for human $\mathrm{KOR}(\mathrm{Ki}=3 \mathrm{nM})$, with approximate 20 -fold selectivity over MOR (MORs; $\mathrm{Ki}=$ $64 \mathrm{nM}$ ) and negligible affinity for DOR receptors (Ki $>4 \mu \mathrm{M}){ }^{[108]}$. In mouse tail-flick assay, the analgesia induced by spiradoline $(5.6 \mathrm{mg} / \mathrm{kg}$ s.c., KOR agonist) and morphine (3.2 mg/kg s.c., MOR agonist) could be reversed by PF-04455242 in a dose dependent pattern, with $\mathrm{ID}_{50}$ values of 1.5 and $9.8 \mathrm{mg} / \mathrm{kg}$, respectively. Moreover, PF-04455242 was as effective as nor-BNI in rodent models of depression, such as mouse forcedswim test and mouse social defeat stress assay. ${ }^{[108]}$

Although its brain penetration capability and potential hERG profile which was associated cardiotoxicity are acceptable, PF-04455242 has some binding affinities for 19 out of 120 off-targets (the proteins targets other than therapeutic purposes ${ }^{[105]}$, posing relevant safety concerns and potential side effects. Furthermore, an KOR occupancy phase-I clinical trial of PF-04455242 was terminated on January 6, 2010, due to toxicology findings in animals exposed to PF-04455242 for three months [ClinicalTrials.gov Identifier: NCT00939887].

\section{AZ-MTAB (20)}

AZ-MTAB, an 8-azabicyclo [3.2.1] octan-3-yloxybenzamide, is a selective KOR antagonist developed by AstraZeneca. ${ }^{[109,110]}$ As shown in the human $\left[{ }^{35} \mathrm{~S}\right]$ GTP $\gamma$ S assay with Dynorphin A(1-13) as the agonist, the KOR antagonistic activity of AZ-MTAB was determined to be $20 \mathrm{nM}$, which showed approximately 30 - and 400-fold selectivity over MOR and DOR antagonism, respectively. ${ }^{[110]}$ Besides having relatively favorable pharmacokinetic profiles, it could reverse KOR agonist induced diuresis in rats. ${ }^{[105]}$ However, due to its relatively high $\mathrm{hERG}$ activity $\left(\mathrm{IC}_{50}=0.26\right.$ $\mu \mathrm{M})$ and the overall hERG liability of this structure class, ${ }^{[105]}$ AZ-MTAB or any structurally related candidates could not enter clinical trials.

\section{Conclusion}

There are currently multiple drug classes available for the treatment of major depressive disorder, including TCAs, MAOIs and SSRIs, as well as SNRIs. However, approximately $30-40 \%$ patients with MDD fail to benefit from these medications, especially for those with treatment-resistant depression responding poorly to at least two antidepressants. The emergence of KOR antagonists seems promisingly to satisfy this unmet medical need. In fact, the efficacy and safety of early off-label use of buprenorphine has been promising in the management of treatment-resistant depression. It seems that ALKS 5461 (a combination of buprenorphine and ALKS-33) is hopeful in entering clinical practice in the near future. Moreover, in consideration of current pre-clinical and clinical evidences, CERC501 (LY-2456302) will be expected to be available as monotherapy or adjuvant therapy with other first-line antidepressants in the management of treatment-resistant depression, if ongoing clinical trials continue to provide positive benefit-risk profiles. Emerging new research interests might bring more useful drug candidates to clinical trials to address the current challenges in MDD treatment in clinical practice. 


\section{Conflict Interests Disclosure:}

The authors have no conflicting interests to disclose.

Corresponding Author:Liming Shao, Ph.D.,

Department of Medicinal Chemistry, School of Pharmacy, at Fudan University, 826 Zhangheng Road, Zhangjiang Hitech Park, Pudong, Shanghai 201203, China;

limingshao@fudan.edu.cn

Editor: Yuan-Xiang Tao, MD, PhD, Department of Anesthesiology, Rutgers New Jersey Medical School, Rutgers, The State University of New Jersey. $185 \mathrm{~S}$. Orange Ave., MSB, F-548, Newark, NJ 07103. Tel: +1-973-972-9812; Fax: +1-973-972-1644.

E-mail: yuanxiang.tao@njms.rutgers.edu

\section{Disclosure of Funding}

This work was funded by National Natural Science Foundation of China 81473076 (PI: LM Shao) and Shanghai Natural Science Foundation 08ZR1401500 (PI: W LI). This work is also funded by NIH 1R01GM111421 (PI: RL).

\section{Additional publication details}

Journal short name: Transl Perioper \& Pain Med

Received Date:Jan 5, 2016

Accepted Date: March 1, 2016

Published Date: March 26, 2016

Transl Perioper \& Pain Med 2016; 1(2):4-16

\section{Citation and Copyright}

Citation: Li W, Sun H, Chen, H, Yang X, Xiao L, Liu R, Shao L, Qiu Z. Major depressive disorder and kappa opioid receptor antagonists. Transl Perioper \& Pain Med 2016; 1(2): 4-16

Copyright: (C) $2016 \mathrm{Li} \mathrm{W}$. et al. This is an open-access article distributed under the terms of the Creative Commons Attribution License, which permits unrestricted use, distribution, and reproduction in any medium, provided the original author and source are credited.

\section{References}

1. WHO. Depression 2015 [cited 2015]. Available from: http://www.who.int/mediacentre/factsheets/fs369/en/.

2. Cecil R, Goldman L, Schafer A. Goldman's Cecil medicine. Philadelphia: Saunders; 2012.

3. Gu L, Xie J, Long J, Chen Q, Chen Q, Pan R, et al. Epidemiology of major depressive disorder in mainland china: a systematic review. PloS one. 2013;8(6):e65356. doi: 10.1371/journal.pone.0065356. PubMed PMID: 23785419; PubMed Central PMCID: PMC3681935.

4. Bromet E, Andrade LH, Hwang I, Sampson NA, Alonso J, de Girolamo G, et al. Cross-national epidemiology of DSM-IV major depressive episode. BMC medicine. 2011;9:90. doi: 10.1186/1741-7015-9-90. PubMed PMID: 21791035 ; PubMed Central PMCID: PMC3163615.

5. Johnson LR. Tricyclic antidepressant toxicosis. The Veterinary clinics of North America Small animal practice. 1990;20(2):393-403. PubMed PMID: 2180186.

6. Brown WA, Rosdolsky M. The clinical discovery of imipramine. The American journal of psychiatry. 2015;172(5):426-9. doi: 10.1176/appi.ajp.2015.14101336. PubMed PMID: 25930134.

7. Levin A. Mianserin and clomipramine in the treatment of depression. South African medical journal. 1982;61(19):701-4. PubMed PMID: 7043754.

8. Loosen PT, Merkel U, Amelung U. Letter: Combined sleep deprivation and clomipramine in primary depression. Lancet. 1976;2(7977):156-7. PubMed PMID: 59234.

9. Mahy GE. The effects of clomipramine on depression in Barbadian patients. The West Indian medical journal. 1978;27(2):75-80. PubMed PMID: 695554.

10. Olie JP, Sechter D. [Clomipramine : its use in depression and diseases other than depression]. Annales medico-psychologiques. 1979;137(3-4):236-45. PubMed PMID: 496147.

11. Kashani JH, Shekim WO, Reid JC. Amitriptyline in children with major depressive disorder: a double-blind crossover pilot study. Journal of the American Academy of Child Psychiatry. 1984;23(3):348-51. PubMed PMID: 6736501 .

12. Leucht C, Huhn M, Leucht S. Amitriptyline versus placebo for major depressive disorder. The Cochrane database of systematic reviews. 2012;12:CD009138. doi: 10.1002/14651858.CD009138.pub2. PubMed PMID: 23235671 .

13. Davidson JR, Giller EL, Zisook S, Overall JE. An efficacy study of isocarboxazid and placebo in depression, and its relationship to depressive nosology. Archives of general psychiatry. 1988;45(2):120-7. PubMed PMID: 


\section{1.}

14. Yochelson S. Isocarboxazid in the treatment of depression. Journal of clinical and experimental psychopathology \& quarterly review of psychiatry and neurology. 1960;21:196-204. PubMed PMID: 13787333.

15. Zisook S. Isocarboxazid in the treatment of depression. The American journal of psychiatry. 1983;140(6):7924. doi: 10.1176/ajp.140.6.792. PubMed PMID: 6342428.

16. Laux G, Beckmann H, Classen W, Becker T. Moclobemide and maprotiline in the treatment of inpatients with major depressive disorder. Journal of neural transmission Supplementum. 1989;28:45-52. PubMed PMID: 2677241.

17. Steinmeyer EM, Vorbach EU, Arnoldt KH. Efficacy and safety of moclobemide compared with maprotiline in treatment of major depressive disorder. A double-blind multicenter study with parallel groups. Pharmacopsychiatry. 1993;26(6):246-53. doi: 10.1055/s-2007-1014362. PubMed PMID: 8127929.

18. Stuhec M, Oravecz R. Moclobemide as add-on therapy to agomelatine in a patient with treatment-resistant major depressive disorder: a psychopharmacological case. Wiener klinische Wochenschrift. 2015. doi: 10.1007/ s00508-015-0861-0. PubMed PMID: 26404738.

19. Fernandez Labriola R, Caetano Esquivel G, Alvarez M, Servidio M. [Toloxatone and depression]. Acta psiquiatrica y psicologica de America latina. 1991;37(4):291-8. PubMed PMID: 1843597.

20. Thase ME. MAOIs and depression treatment guidelines. The Journal of clinical psychiatry. 2012;73(7):e24. doi: 10.4088/JCP.11096tx4c. PubMed PMID: 22901357.

21. Thase ME, Trivedi MH, Rush AJ. MAOIs in the contemporary treatment of depression. Neuropsychopharmacology : official publication of the American College of Neuropsychopharmacology. 1995;12(3):185-219. doi: 10.1016/0893-133X(94)00058-8. PubMed PMID: 7612154.

22. Mallet L, Schittecatte M. [Monoamine oxidase inhibitors and food precautions. A comparison of utilization in Belgian psychiatric education institutes and current findings in the literature]. Acta psychiatrica Belgica. 1996;96(2):74-100. PubMed PMID: 8693949.

23. Perrault M. [Monoamine oxidase inhibitors (MAOI) and food products]. Semaine therapeutique. 1965;41(5):284-7. PubMed PMID: 4383266.

24. Ryan ND, Puig-Antich J, Rabinovich H, Fried J,
Ambrosini P, Meyer V, et al. MAOIs in adolescent major depression unresponsive to tricyclic antidepressants. Journal of the American Academy of Child and Adolescent Psychiatry. 1988;27(6):755-8. doi: 10.1097/00004583198811000-00016. PubMed PMID: 3198564.

25. Jakubovski E, Varigonda AL, Freemantle N, Taylor MJ, Bloch MH. Systematic Review and Meta-Analysis: Dose-Response Relationship of Selective Serotonin Reuptake Inhibitors in Major Depressive Disorder. The American journal of psychiatry. 2015:appiajp201515030331. doi: 10.1176/appi.ajp.2015.15030331. PubMed PMID: 26552940 .

26. Apler A. Citalopram for major depressive disorder in adults: a systematic review and meta-analysis of published placebo-controlled trials. BMJ open. 2011;1(2):e000106. doi: 10.1136/bmjopen-2011-000106. PubMed PMID: 22021869; PubMed Central PMCID: PMC3191585.

27. Sonawalla SB. Citalopram in the maintenance treatment of major depressive disorder. The Journal of clinical psychiatry. 2001;62(12):993. PubMed PMID: 11780882 .

28. Azorin JM, Llorca PM, Despiegel N, Verpillat P. [Escitalopram is more effective than citalopram for the treatment of severe major depressive disorder]. L'Encephale. 2004;30(2):158-66. PubMed PMID: 15107719.

29. Gorman JM, Korotzer A, Su G. Efficacy comparison of escitalopram and citalopram in the treatment of major depressive disorder: pooled analysis of placebo-controlled trials. CNS spectrums. 2002;7(4 Suppl 1):40-4.

PubMed PMID: 15131492.

30. Lancon C, Verpillat P, Annemans L, Despiegel N, Francois C. Escitalopram in major depressive disorder: clinical benefits and cost effectiveness versus citalopram. International journal of psychiatry in clinical practice. 2007;11(1):44-52. doi: 10.1080/13651500600874527. PubMed PMID: 24941275.

31. Muijsers RB, Plosker GL, Noble S. Sertraline: a review of its use in the management of major depressive disorder in elderly patients. Drugs \& aging. 2002;19(5):37792. PubMed PMID: 12093324.

32. Reimherr FW, Byerley WF, Ward MF, Lebegue BJ, Wender PH. Sertraline, a selective inhibitor of serotonin uptake, for the treatment of outpatients with major depressive disorder. Psychopharmacology bulletin. 1988;24(1):200-5. PubMed PMID: 3290941.

33. Wagner KD, Ambrosini P, Rynn M, Wohlberg C, 
Yang R, Greenbaum MS, et al. Efficacy of sertraline in the treatment of children and adolescents with major depressive disorder: two randomized controlled trials. Jama. 2003;290(8):1033-41. doi: 10.1001/jama.290.8.1033. PubMed PMID: 12941675.

34. Wenthur CJ, Bennett MR, Lindsley CW. Classics in Chemical Neuroscience: Fluoxetine (Prozac). Acs Chemical Neuroscience. 2014;5(1):14-23. doi: 10.1021/ cn400186j. PubMed PMID: WOS:000330018300002.

35. Courtney DB. Selective serotonin reuptake inhibitor and venlafaxine use in children and adolescents with major depressive disorder: a systematic review of published randomized controlled trials. Canadian journal of psychiatry Revue canadienne de psychiatrie. 2004;49(8):557-63. PubMed PMID: 15453105.

36. Silverstone PH, Salinas E. Efficacy of venlafaxine extended release in patients with major depressive disorder and comorbid generalized anxiety disorder. The Journal of clinical psychiatry. 2001;62(7):523-9. PubMed PMID: 11488362 .

37. Wise TN, Sheridan MJ. Venlafaxine versus sertraline for major depressive disorder. The Journal of clinical psychiatry. 2000;61(11):873-4. PubMed PMID: 11105744.

38. Ball SG, Desaiah D, Zhang Q, Thase ME, Perahia DG. Efficacy and safety of duloxetine $60 \mathrm{mg}$ once daily in major depressive disorder: a review with expert commentary. Drugs in context. 2013;2013:212245. doi: 10.7573/ dic.212245. PubMed PMID: 24432034; PubMed Central PMCID: PMC3884746.

39. Maund E, Tendal B, Hrobjartsson A, Jorgensen KJ, Lundh A, Schroll J, et al. Benefits and harms in clinical trials of duloxetine for treatment of major depressive disorder: comparison of clinical study reports, trial registries, and publications. Bmj. 2014;348:g3510. doi: 10.1136/ bmj.g3510. PubMed PMID: 24899650; PubMed Central PMCID: PMC4045316.

40. Olie JP, Gourion D, Montagne A, Rostin M, Poirier MF. Milnacipran and venlafaxine at flexible doses (up to $200 \mathrm{mg}$ /day) in the outpatient treatment of adults with moderate-to-severe major depressive disorder: a 24-week randomized, double-blind exploratory study. Neuropsychiatric disease and treatment. 2010;6:71-9. PubMed PMID: 20396639; PubMed Central PMCID: PMC2854083.

41. Papakostas GI, Fava M. A meta-analysis of clinical trials comparing milnacipran, a serotonin--norepinephrine reuptake inhibitor, with a selective serotonin reuptake inhibitor for the treatment of major depressive disorder. European neuropsychopharmacology : the journal of the European College of Neuropsychopharmacology. 2007;17(1):32-6. doi: 10.1016/j.euroneuro.2006.05.001. PubMed PMID: 16762534.

42. Machado M, Einarson TR. Comparison of SSRIs and SNRIs in major depressive disorder: a meta-analysis of head-to-head randomized clinical trials. J Clin Pharm Ther. 2010;35(2):177-88. doi: 10.1111/j.1365-2710.2009.01050.x. PubMed PMID: WOS:000275212100006.

43. Zajecka JM, Albano D. SNRIs in the management of acute major depressive disorder. The Journal of clinical psychiatry. 2004;65 Suppl 17:11-8. PubMed PMID: 15600377.

44. Artigas F. Limitations to enhancing the speed of onset of antidepressants - are rapid action antidepressants possible? Human psychopharmacology. 2001;16(1):29-36. doi: 10.1002/hup.180. PubMed PMID: 12404595.

45. Korte SM, Prins J, Krajnc AM, Hendriksen H, Oosting RS, Westphal KG, et al. The many different faces of major depression: it is time for personalized medicine. European journal of pharmacology. 2015;753:88-104. doi: 10.1016/j.ejphar.2014.11.045. PubMed PMID: 25592320.

46. Shao L, Li W, Xie Q, Yin H. Triple reuptake inhibitors: a patent review (2006 - 2012). Expert opinion on therapeutic patents. 2014;24(2):131-54. doi: 10.1517/13543776.2014.859676. PubMed PMID: 24289044.

47. Masand PS. Tolerability and adherence issues in antidepressant therapy. Clinical therapeutics. 2003;25(8):2289-304. PubMed PMID: 14512135.

48. Montgomery SA, Henry J, McDonald G, Dinan T, Lader M, Hindmarch I, et al. Selective serotonin reuptake inhibitors: meta-analysis of discontinuation rates. International clinical psychopharmacology. 1994;9(1):47-53. PubMed PMID: 8195583.

49. Nomura S. [Problems of current antidepressant drugs]. Nihon shinkei seishin yakurigaku zasshi $=$ Japanese journal of psychopharmacology. 2003;23(2):61-5. PubMed PMID: 12762217.

50. Adegbite-Adeniyi C, Gron B, Rowles BM, Demeter CA, Findling RL. An update on antidepressant use and suicidality in pediatric depression. Expert opinion on pharmacotherapy. 2012;13(15):2119-30. doi: 10.1517/14656566.2012.726613. PubMed PMID: 22984934.

51. Gibbons RD, Brown CH, Hur K, Marcus SM, 
Bhaumik DK, Erkens JA, et al. Early evidence on the effects of regulators' suicidality warnings on SSRI prescriptions and suicide in children and adolescents. The American journal of psychiatry. 2007;164(9):1356-63. doi: 10.1176/ appi.ajp.2007.07030454. PubMed PMID: 17728420.

52. Holtmann M, Bolte S, Poustka F. [Suicidality in depressive children and adolescents during treatment with selective serotonin reuptake inhibitors. Review and meta-analysis of the available randomised, placebo controlled trials]. Der Nervenarzt. 2006;77(11):1332-7. doi: 10.1007/ s00115-005-1952-3. PubMed PMID: 15986258.

53. Tandt H, Audenaert K, van Heeringen C. [SSRIs (selective serotonin reuptake inhibitors) and suicidality in adults, adolescents and children]. Tijdschrift voor psychiatrie. 2009;51(6):387-93. PubMed PMID: 19517368.

54. Ribeiro SC, Kennedy SE, Smith YR, Stohler CS, Zubieta JK. Interface of physical and emotional stress regulation through the endogenous opioid system and mu-opioid receptors. Progress in neuro-psychopharmacology \& biological psychiatry. 2005;29(8):1264-80. doi: 10.1016/j. pnpbp.2005.08.011. PubMed PMID: 16256255.

55. White KL, Roth BL. Psychotomimetic effects of kappa opioid receptor agonists. Biological psychiatry. 2012;72(10):797-8. doi: 10.1016/j.biopsych.2012.08.014. PubMed PMID: 23083945.

56. Wang YH, Sun JF, Tao YM, Chi ZQ, Liu JG. The role of kappa-opioid receptor activation in mediating antinociception and addiction. Acta pharmacologica Sinica. 2010;31(9):1065-70. doi: 10.1038/aps.2010.138. PubMed PMID: 20729876; PubMed Central PMCID: PMC4002313.

57. Bruchas MR, Land BB, Chavkin C. The dynorphin/ kappa opioid system as a modulator of stress-induced and pro-addictive behaviors. Brain research. 2010;1314:4455. doi: 10.1016/j.brainres.2009.08.062. PubMed PMID: 19716811; PubMed Central PMCID: PMC2819621.

58. Crowley NA, Kash TL. Kappa opioid receptor signaling in the brain: Circuitry and implications for treatment. Progress in neuro-psychopharmacology \& biological psychiatry. 2015;62:51-60. doi: 10.1016/j.pnpbp.2015.01.001. PubMed PMID: 25592680; PubMed Central PMCID: PMC4465498.

59. Grella SL, Funk D, Coen K, Li Z, Le AD. Role of the kappa-opioid receptor system in stress-induced reinstatement of nicotine seeking in rats. Behavioural brain research. 2014;265:188-97. doi: 10.1016/j.bbr.2014.02.029. PubMed PMID: 24583188; PubMed Central PMCID: PMC4082245.
60. Leitl MD, Onvani S, Bowers MS, Cheng K, Rice $\mathrm{KC}$, Carlezon WA, Jr., et al. Pain-related depression of the mesolimbic dopamine system in rats: expression, blockade by analgesics, and role of endogenous kappa-opioids. Neuropsychopharmacology : official publication of the American College of Neuropsychopharmacology. 2014;39(3):614-24. doi: 10.1038/npp.2013.236. PubMed PMID: 24008352; PubMed Central PMCID: PMC3895239.

61. Sirohi S, Bakalkin G, Walker BM. Alcohol-induced plasticity in the dynorphin/kappa-opioid receptor system. Frontiers in molecular neuroscience. 2012;5:95. doi: 10.3389/fnmol.2012.00095. PubMed PMID: 23060746; PubMed Central PMCID: PMC3459013.

62. Lutz PE, Kieffer BL. Opioid receptors: distinct roles in mood disorders. Trends in neurosciences. 2013;36(3):195-206. doi: 10.1016/j.tins.2012.11.002. PubMed PMID: 23219016; PubMed Central PMCID: PMC3594542.

63. Larson DL, Jones RM, Hjorth SA, Schwartz TW, Portoghese PS. Binding of norbinaltorphimine (norBNI) congeners to wild-type and mutant mu and kappa opioid receptors: molecular recognition loci for the pharmacophore and address components of kappa antagonists. J Med Chem. 2000;43(8):1573-6. PubMed PMID: 10780914.

64. Lalanne L, Ayranci G, Kieffer BL, Lutz PE. The kappa opioid receptor: from addiction to depression, and back. Frontiers in psychiatry. 2014;5:170. doi: 10.3389/ fpsyt.2014.00170. PubMed PMID: 25538632; PubMed Central PMCID: PMC4258993.

65. Mague SD, Pliakas AM, Todtenkopf MS, Tomasiewicz HC, Zhang Y, Stevens WC, Jr., et al. Antidepressant-like effects of kappa-opioid receptor antagonists in the forced swim test in rats. The Journal of pharmacology and experimental therapeutics. 2003;305(1):323-30. doi: 10.1124/jpet.102.046433. PubMed PMID: 12649385.

66. Newton SS, Thome J, Wallace TL, Shirayama Y, Schlesinger L, Sakai N, et al. Inhibition of cAMP response element-binding protein or dynorphin in the nucleus accumbens produces an antidepressant-like effect. The Journal of neuroscience : the official journal of the Society for Neuroscience. 2002;22(24):10883-90. PubMed PMID: 12486182.

67. Beardsley PM, Howard JL, Shelton KL, Carroll FI. Differential effects of the novel kappa opioid receptor antagonist, JDTic, on reinstatement of cocaine-seeking induced by footshock stressors vs cocaine primes and its antidepressant-like effects in rats. Psychopharmacology. 2005;183(1):118-26. doi: 10.1007/s00213-005-0167-4. 
PubMed PMID: 16184376.

68. Beardsley PM, Pollard GT, Howard JL, Carroll FI. Effectiveness of analogs of the kappa opioid receptor antagonist (3R)-7-hydroxy-N-((1S)-1-\{[(3R,4R)4-(3-hydroxyphenyl)-3,4-dimethyl-1-piperidinyl ] methyl \}-2-methylpropyl)-1,2,3,4-tetrahydro-3-isoquinolinecarboxamide (JDTic) to reduce U50,488-induced diuresis and stress-induced cocaine reinstatement in rats. Psychopharmacology. 2010;210(2):189-98. doi: 10.1007/s00213-010-1846-3. PubMed PMID: 20372878; PubMed Central PMCID: PMC2872796.

69. Tejedor-Real P, Mico JA, Maldonado R, Roques BP, Gibert-Rahola J. Implication of endogenous opioid system in the learned helplessness model of depression. Pharmacology, biochemistry, and behavior. 1995;52(1):145-52. PubMed PMID: 7501657.

70. Von Voigtlander PF, Lewis RA. U-50,488, a selective kappa opioid agonist: comparison to other reputed kappa agonists. Progress in neuro-psychopharmacology \& biological psychiatry. 1982;6(4-6):467-70. PubMed PMID: 6298890.

71. Pande AC, Pyke RE, Greiner M, Wideman GL, Benjamin R, Pierce MW. Analgesic efficacy of enadoline versus placebo or morphine in postsurgical pain. Clinical neuropharmacology. 1996;19(5):451-6. PubMed PMID: 8889289.

72. Ur E, Wright DM, Bouloux PM, Grossman A. The effects of spiradoline (U-62066E), a kappa-opioid receptor agonist, on neuroendocrine function in man. British journal of pharmacology. 1997;120(5):781-4. doi: 10.1038/sj.bjp.0700971. PubMed PMID: 9138682; PubMed Central PMCID: PMC1564535.

73. Portoghese PS, Lipkowski AW, Takemori AE. Bimorphinans as Highly Selective, Potent-K Opioid Receptor Antagonists. J Med Chem. 1987;30(2):2389. doi: Doi 10.1021/Jm00385a002. PubMed PMID: WOS:A1987F738700002.

74. Portoghese PS, Nagase H, Takemori AE. Stereochemical Studies on Medicinal Agents .31. Only One Pharmacophore Is Required for the K-Opioid Antagonist Selectivity of Norbinaltorphimine. J Med Chem. 1988;31(7):1344-7. doi: Doi 10.1021/Jm00402a015. PubMed PMID: WOS:A1988P035700015.

75. Portoghese PS, Garzonaburbeh A, Nagase H, Lin CE, Takemori AE. Role of the Spacer in Conferring Kappa-Opioid Receptor Selectivity to Bivalent Ligands Related to Norbinaltorphimine. J Med Chem. 1991;34(4):1292-6. doi: Doi 10.1021/Jm00108a008.
PubMed PMID: WOS:A1991FG77600008.

76. Portoghese PS, Nagase H, Lipkowski AW, Larson DL, Takemori AE. Binaltorphimine-Related Bivalent Ligands and Their Kappa-Opioid Receptor Antagonist Selectivity. J Med Chem. 1988;31(4):836-41. doi: Doi 10.1021/ Jm00399a026. PubMed PMID: WOS:A1988M716200026.

77. Takemori AE, Ho BY, Naeseth JS, Portoghese PS. Nor-binaltorphimine, a highly selective kappa-opioid antagonist in analgesic and receptor binding assays. The Journal of pharmacology and experimental therapeutics. 1988;246(1):255-8. PubMed PMID: 2839664.

78. Kishioka S, Kiguchi N, Kobayashi Y, Yamamoto C, Saika F, Wakida N, et al. Pharmacokinetic evidence for the long-lasting effect of nor-binaltorphimine, a potent kappa opioid receptor antagonist, in mice. Neuroscience letters. 2013;552:98-102. doi: 10.1016/j.neulet.2013.07.040. PubMed PMID: 23933210.

79. Horan P, Taylor J, Yamamura HI, Porreca F. Extremely long-lasting antagonistic actions of nor-binaltorphimine (nor-BNI) in the mouse tail-flick test. The Journal of pharmacology and experimental therapeutics. 1992;260(3):1237-43. PubMed PMID: 1312164.

80. Jones RM, Portoghese PS. 5'-Guanidinonaltrindole, a highly selective and potent kappa-opioid receptor antagonist. European journal of pharmacology. 2000;396(1):49-52. PubMed PMID: 10822054.

81. Sharma SK, Jones RM, Metzger TG, Ferguson DM, Portoghese PS. Transformation of a kappa-opioid receptor antagonist to a kappa-agonist by transfer of a guanidinium group from the 5'- to 6'-position of naltrindole. J Med Chem. 2001;44(13):2073-9. PubMed PMID: 11405645 .

82. Negus SS, Mello NK, Linsenmayer DC, Jones RM, Portoghese PS. Kappa opioid antagonist effects of the novel kappa antagonist 5'-guanidinonaltrindole (GNTI) in an assay of schedule-controlled behavior in rhesus monkeys. Psychopharmacology. 2002;163(3-4):412-9. doi: 10.1007/ s00213-002-1038-x. PubMed PMID: 12373442.

83. Munro TA, Berry LM, Van't Veer A, Beguin C, Carroll FI, Zhao Z, et al. Long-acting kappa opioid antagonists nor-BNI, GNTI and JDTic: pharmacokinetics in mice and lipophilicity. BMC pharmacology. 2012;12:5. doi: 10.1186/1471-2210-12-5. PubMed PMID: 22642416; PubMed Central PMCID: PMC3411462.

84. Heel RC, Brogden RN, Speight TM, Avery GS. Buprenorphine: a review of its pharmacological properties and therapeutic efficacy. Drugs. 1979;17(2):81-110. PubMed 
PMID: 378645.

85. Bouchez J, Beauverie P, Touzeau D. Substitution with buprenorphine in methadone- and morphine sulfate-dependent patients. Preliminary results. European addiction research. 1998;4 Suppl 1:8-12. PubMed PMID: 9767200 .

86. Vignau J. Preliminary assessment of a 10-day rapid detoxification programme using high dosage buprenorphine. European addiction research. 1998;4 Suppl 1:29-31. PubMed PMID: 9767204.

87. Petitjean S, Stohler R, Deglon JJ, Livoti S, Waldvogel D, Uehlinger C, et al. Double-blind randomized trial of buprenorphine and methadone in opiate dependence. Drug and alcohol dependence. 2001;62(1):97-104. PubMed PMID: 11173173.

88. Emrich HM, Vogt P, Herz A. Possible antidepressive effects of opioids: action of buprenorphine. Annals of the New York Academy of Sciences. 1982;398:108-12. PubMed PMID: 6760767.

89. Nyhuis PW, Gastpar M, Scherbaum N. Opiate treatment in depression refractory to antidepressants and electroconvulsive therapy. Journal of clinical psychopharmacology. 2008;28(5):593-5. doi: 10.1097/

JCP.0b013e31818638a4. PubMed PMID: 18794671.

90. Bodkin JA, Zornberg GL, Lukas SE, Cole JO. Buprenorphine treatment of refractory depression. Journal of clinical psychopharmacology. 1995;15(1):49-57. PubMed PMID: 7714228.

91. Karp JF, Butters MA, Begley AE, Miller MD, Lenze EJ, Blumberger DM, et al. Safety, tolerability, and clinical effect of low-dose buprenorphine for treatment-resistant depression in midlife and older adults. The Journal of clinical psychiatry. 2014;75(8):e785-93. doi: 10.4088/ JCP.13m08725. PubMed PMID: 25191915; PubMed Central PMCID: PMC4157317.

92. Wolff RF, Reid K, di Nisio M, Aune D, Truyers C, Hernandez AV, et al. Systematic review of adverse events of buprenorphine patch versus fentanyl patch in patients with chronic moderate-to-severe pain. Pain management. 2012;2(4):351-62. doi: 10.2217/pmt.12.22. PubMed PMID: 24654721 .

93. Ray R, Pal H, Kumar R, Maulick P, Mangla R. Post-marketing surveillance of buprenorphine. Pharmacoepidemiology and drug safety. 2004;13(9):615-9. doi: 10.1002/pds.975. PubMed PMID: 15362084.

94. Zimmerman DM, Nickander R, Horng JS,
Wong DT. New structural concepts for narcotic antagonists defined in a 4-phenylpiperidine series. Nature. 1978;275(5678):332-4. PubMed PMID: 692714.

95. Thomas JB, Fall MJ, Cooper JB, Rothman $\mathrm{RB}$, Mascarella SW, Xu H, et al. Identification of an opioid kappa receptor subtype-selective $\mathrm{N}$-substituent for $(+)-(3 R, 4 R)$-dimethyl-4-(3-hydroxyphenyl)piperidine. J Med Chem. 1998;41(26):5188-97. doi: 10.1021/ jm980511k. PubMed PMID: 9857089.

96. Thomas JB, Atkinson RN, Rothman RB, Fix SE, Mascarella SW, Vinson NA, et al. Identification of the first trans-(3R,4R)- dimethyl-4-(3-hydroxyphenyl)piperidine derivative to possess highly potent and selective opioid kappa receptor antagonist activity. J Med Chem. 2001;44(17):2687-90. PubMed PMID: 11495579.

97. Carroll FI, Gichinga MG, Kormos CM, Maitra R, Runyon SP, Thomas JB, et al. Design, synthesis, and pharmacological evaluation of JDTic analogs to examine the significance of the 3- and 4-methyl substituents. Bioorganic \& medicinal chemistry. 2015;23(19):6379-88. doi: 10.1016/j.bmc.2015.08.025. PubMed PMID: 26342544; PubMed Central PMCID: PMC4582009.

98. Carroll I, Thomas JB, Dykstra LA, Granger AL, Allen RM, Howard JL, et al. Pharmacological properties of JDTic: a novel kappa-opioid receptor antagonist. European journal of pharmacology. 2004;501(1-3):111-9. doi: 10.1016/j.ejphar.2004.08.028. PubMed PMID: 15464069.

99. Jackson KJ, Carroll FI, Negus SS, Damaj MI. Effect of the selective kappa-opioid receptor antagonist JDTic on nicotine antinociception, reward, and withdrawal in the mouse. Psychopharmacology. 2010;210(2):28594. doi: 10.1007/s00213-010-1803-1. PubMed PMID: 20232057; PubMed Central PMCID: PMC2866121.

100. Schank JR, Goldstein AL, Rowe KE, King CE, Marusich JA, Wiley JL, et al. The kappa opioid receptor antagonist JDTic attenuates alcohol seeking and withdrawal anxiety. Addiction biology. 2012;17(3):634-47. doi: 10.1111/j.1369-1600.2012.00455.x. PubMed PMID: 22515275; PubMed Central PMCID: PMC3334348.

101. Deehan GA, Jr., McKinzie DL, Carroll FI, McBride WJ, Rodd ZA. The long-lasting effects of JDTic, a kappa opioid receptor antagonist, on the expression of ethanol-seeking behavior and the relapse drinking of female alcohol-preferring $(\mathrm{P})$ rats. Pharmacology, biochemistry, and behavior. 2012;101(4):581-7 doi: 10.1016/j. pbb.2012.03.006. PubMed PMID: 22429993; PubMed Central PMCID: PMC3327789.

102. Carroll FI, Harris LS, Aceto MD. Effects of 
JDTic, a selective kappa-opioid receptor antagonist, on the development and expression of physical dependence on morphine using a rat continuous-infusion model. European journal of pharmacology. 2005;524(1-3):89-94. doi: 10.1016/j.ejphar.2005.09.013. PubMed PMID: 16236279.

103. Chavkin C, Martinez D. Kappa Antagonist JDTic in Phase 1 Clinical Trial. Neuropsychopharmacology : official publication of the American College of Neuropsychopharmacology. 2015;40(9):2057-8. doi: 10.1038/ npp.2015.74. PubMed PMID: 26174493; PubMed Central PMCID: PMC4613619.

104. Buda JJ, Carroll FI, Kosten TR, Swearingen D, Walters BB. A Double-Blind, Placebo-Controlled Trial to Evaluate the Safety, Tolerability, and Pharmacokinetics of Single, Escalating Oral Doses of JDTic. Neuropsychopharmacology : official publication of the American College of Neuropsychopharmacology. 2015;40(9):2059-65. doi: 10.1038/npp.2015.27. PubMed PMID: 25628006; PubMed Central PMCID: PMC4613600.

105. Urbano M, Guerrero M, Rosen H, Roberts E. Antagonists of the kappa opioid receptor. Bioorganic \& medicinal chemistry letters. 2014;24(9):2021-32. doi: 10.1016/j.bmcl.2014.03.040. PubMed PMID: 24690494.

106. Rorick-Kehn LM, Witkin JM, Statnick MA, Eberle EL, McKinzie JH, Kahl SD, et al. LY2456302 is a novel, potent, orally-bioavailable small molecule kappa-selective antagonist with activity in animal models predictive of efficacy in mood and addictive disorders. Neuropharmacology. 2014;77:131-44. doi: 10.1016/j.neuropharm.2013.09.021. PubMed PMID: WOS:000330490000013.

107. Lowe SL, Wong CJ, Witcher J, Gonzales CR, Dickinson GL, Bell RL, et al. Safety, tolerability, and pharmacokinetic evaluation of single- and multiple-ascending doses of a novel kappa opioid receptor antagonist LY2456302 and drug interaction with ethanol in healthy subjects. J Clin Pharmacol. 2014;54(9):968-78. doi: 10.1002/jcph.286. PubMed PMID: WOS:000340447400002.

108. Grimwood S, Lu Y, Schmidt AW, Vanase-Frawley MA, Sawant-Basak A, Miller E, et al. Pharmacological characterization of 2-methyl-N-((2'-(pyrrolidin-1-ylsulfonyl)biphenyl-4-yl) methyl)propan-1-amine (PF-04455242), a high-af- finity antagonist selective for kappa-opioid receptors. The Journal of pharmacology and experimental therapeutics. 2011;339(2):555-66. doi: 10.1124/ jpet.111.185108. PubMed PMID: 21821697.

109. Brugel TA, Smith RW, Balestra M, Becker C, Daniels T, Koether GM, et al. SAR development of a series of 8-azabicyclo[3.2.1] octan-3-yloxy-benzamides as kappa opioid receptor antagonists. Part 2. Bioorganic \& medicinal chemistry letters. 2010;20(18):540510. doi: 10.1016/j.bmcl.2010.07.112. PubMed PMID: 20719509.

110. Brugel TA, Smith RW, Balestra M, Becker C, Daniels T, Hoerter TN, et al. Discovery of 8-azabicyclo[3.2.1] octan-3-yloxy-benzamides as selective antagonists of the kappa opioid receptor. Part 1. Bioorganic \& medicinal chemistry letters. 2010;20(19):5847-52. doi: 10.1016/j.bmcl.2010.07.113. PubMed PMID: 20727752. 